\title{
ANALYSIS OF THE IMPACT OF RESTAURANT PERCEPTION THROUGH CUSTOMER PERCEIVED VALUE ON CUSTOMER SATISFACTION AND REPURCHASE INTENTION: A CASE STUDY OF O'REILLYS RESTAURANT IN MANADO, INDONESIA
}

\author{
${ }^{1 *}$ Jitro Gianfranco Behuku, ${ }^{2}$ Ronald Suryaputra, ${ }^{3}$ Yanuar Dananjaya \\ ${ }^{1}$ Magister Manajemen Department, Pelita Harapan University, Surabaya, Indonesia \\ ${ }^{2,3}$ Lecturer at Magister Manajemen Department, Pelita Harapan University, Surabaya, Indonesia \\ *Corresponding Author
}

DOI: 10.46609/IJSSER.2020.v05i01.014 URL: https://doi.org/10.46609/IJSSER.2020.v05i01.014

\begin{abstract}
This Research was made to see the impact of factors affecting the rate of Repurchase Intention, and Customer Satisfaction influenced through Customer Perceived Value, by Quality of Food, Quality of Service and Quality of Physical Environment. The use of these variables is a modified replication of the previous study of Yrjola et al (2019), which found that satisfaction with the restaurant experience can be driven by emotions, as social food is often to honor Celebrations, special events, or achievements. The Population of this research is O'reillys restaurant consumers with a number of samples of 160 people. Using the Structural Equation Modelling (SEM) method that is run with AMOS software, used to analyze the data, the analysis results show that Physical Environment positive significantly affect Customer Perceived Value, Customer Perceived Value positive significantly affect Customer Satisfaction and Customer Satisfaction Positive Significantly affect Repurchase Intention. Many studies support the result of this research, but some are contrary. However, the research was limited to the restaurant O'reillys and indicated that to improve Customer Satisfaction and Repurchase Intention, O'reillys Restaurant needs to improve the Quality of Physical Environment.
\end{abstract}

Keywords: Structural Equation Model, AMOS, Perceprion of Restaurant, Customer Perceived Value, Customer Satisfaction, Repurchase Intention

\section{INTRODUCTION}




\section{International Journal of Social Science and Economic Research}

ISSN: $2455-8834$

Volume: 05, Issue: 01 "January 2020"

In this age, the people of Indonesia, especially those living in areas such as the city of Manado, experienced a lifestyle change. Eating and drinking is not only to fulfill the basic need, also has become one of the activities to socialize with the calculation of prestige. It is accompanied by economic growth in the higher city of Manado. According to the Central Statistical Agency report (2016), there was a 7.19 percent economic growth of Manado and became the first rank in the province of North Sulawesi even higher than the North Sulawersi province which grew by 6.17 percent. One that affects the high economic growth in the city of Manado is the business of food and beverage services such as restaurants and eateries that are increasingly mushed in the city of Manado.

According to Rachmawati (2011) says that spending time outside of home with family, spouse, friends or colleagues does not miss just a chat, but while enjoying food and drinks, this makes them to always look for Something that is practical and instant in fulfilling their body needs. One of them is looking for food and beverages outside the home, this makes a lot of food and beverage business that started from small-scale food business such as restaurant and Café Tent, medium-scale food business such as: Depot, Restaurant and Café, up to large-scale food business such as starred restaurants.

The restaurant, according to Marsum (2005), is a commercially organized place or building, which organizes good service to all its guests both eating and drinking. Meanwhile, according to Sulartiningrum (2003) restaurant is a place identical with the array of tables neatly arranged, with the presence of people, the emergence of the scent of the kitchen and the waiter's service, the sound of small noise because The touch of glass cups, porcelain, causing the atmosphere of life in it.

O'Reillys Restaurant is one of the restaurants that puts the optimal value of service for its customers. Because of this, the quality of service is one of the things that is being staged at O'Reillys restaurant. Various operational standards have been established by the management to be applied to all layers of labor for the smoothness and quality of service optimal to be given to the customers. However, not all labor implements these standards and rules, there are still a lot of labor that violates both deliberately, such as ignoring and lazy nature, as well as inadvertently, due to lack of knowledge of the rules or Carelessness. In fact, Labor is one of the major valuation milestones of the quality of service provided by a restaurant, no exception O'Reillys restaurant. Through the review provided by consumers, obtained irregularities - irregularities made by waiter that do not conform to restaurant standards, such as customers who are not tagged waiter when they want to choose food, lack of awareness to Not in front of customers, have no initiative to recommend food or beverage products to customers, and various other issues. The problems in the service to these customers are important to be lifted because they will have an impact on the 
International Journal of Social Science and Economic Research

ISSN: $2455-8834$

Volume: 05, Issue: 01 "January 2020"

customer's assessment of O'Reillys Restaurant restaurant as a whole. Therefore, it is necessary to repair the quality of service provided by the O'Reillys restaurant against the customers, so that customers will be satisfied and will eventually do repeat buying and also provide recommendation to the customer relatives to make a purchase at O'Reillys restaurant.

This Research attempted to study the impact of Restaurant Perception (Quality of Food, Quality of Service, and Quality of Physical Environment) through Customer Perceived Value as intervening variable on Customer Satisfaction and Repurchase Intention in O'reillys Restaurant Manado, Indonesia.

\section{LITERATURE REVIEW}

\subsection{Quality of Food}

According to Kotler \& Armstrong (2012) product as Anything that can be offered to a market for attention, acquisition, use, or consumption that might satisfy a want or need. Therefore, the product is easy to see and compared to consumers. So, the look of the product is made interesting to make consumers interested in the product. After interested consumers want to make a purchase. When consuming the product, consumers will feel that the product is in accordance with the expectation or not. Then the product quality is noticed by the company. This will lead to customer satisfaction. The quality of a food product is very important for any company founder of food vendors, as according to Potter and Hotchkiss (1995) The quality of food is the quality characteristic of food that is acceptable for consumers. This is included in external factors such as size, shape, color, consistency, texture, and flavor. Meanwhile, West, Wood and Harger (1965) also stated that the standard Quality of food, although difficult to define and cannot be measured, but can be evaluated through its nutritional value, the level of material that is taste, and appearance of the product.

H1: Quality of Food has a significant impact on Customer Perceived Value

\subsection{Quality of Service}

According to Kotler (2002) The definition of service is any action or activity that a party may offer to another party, which is essentially intangible and does not result in any ownership. The production can be attributed or not attributed to a single physical product. Service is the behavior of producers in order to fulfill the needs and desires of consumers in order to achieve satisfaction on the consumer itself. Kotler (2002) also says that such behavior can occur at the time, before and after the occurrence of the transaction. In general, high-grade service will result in high satisfaction and more frequent repurchase. The definition of service quality is a model that illustrates the customer's condition in shaping the expectations of service from past experiences, 


\section{International Journal of Social Science and Economic Research}

ISSN: $2455-8834$

Volume: 05, Issue: 01 "January 2020"

word-of-mouth promotion, and advertising by comparing the services they expect with what they receive or feel (Kotler, 2002). According to Tjiptono (2012) The quality of service is something perceived by the customer. Quality of service is a result of subjective evaluation of consumerbased comparisons between expectations and performance of service providers or services perceived (Parasuraman et al., 1988). Service quality at the restaurant can be assessed. In terms of its reliability and consistency of service, willingness to help, hospitality, and staff knowledge (Liu and Jang, 2009; Namkung and Jang, 2008; and Ryu and Han, 2010).

H2: Quality of Service has a significant impact on Customer Perceived Value

\subsection{Quality of Physical Environment}

Physical environment is one of the elements of service. Nowadays the physical environment is no longer a complementary product but also serves as a value-added giver for the product. According to Lovelock, Wirtz, Keh and Lu (2005) states Physical evidence is all visible cues that provide tangible evidence of a firmware's quality and it can have a profound impact on customer's impressions. According to Zeithaml, Bitner and Gramler (2006) Physical evidence is the environment in which the service is delivered and where the firm and customer interact and any tangible components that facilitate performance of communication of the service. It can be interpreted that, the physical environment is a environment where services are provided and as a place to interact with companies with consumers and real components that facilitate the intent of the services produced.

H3: Quality of Physical Environment has a significant impact on Customer Perceived Value

\subsection{Customer Perceived Value}

According to Lai (2004) Perceived value is the overall consumer assessment of the benefits of the product based on what they receive and what they provide. The value indicates the trade-off between the components provided and the consumer acquired, perceived value is the difference in the total value of consumers and total cost of consumers (Lin, 2003). According to Kotler (2008) stated Customer perceived value is the difference between the perspective customer's evaluation of all benefits and all the costs of an offering and the perceived alternatives. The definition of customer perceived value according to Zeithaml (1988) is Perceived value is the Consumer's overall assessment of the utility of a product based on perception of what is received and what is given. The customer's Perceived value is the overall customer's assessment of the usefulness of a product for what it receives and what the product does.

H4: Customer Perceived Value has a significant impact on Customer Satisfaction 
International Journal of Social Science and Economic Research

ISSN: 2455-8834

Volume: 05, Issue: 01 "January 2020"

\subsection{Repurchase Intention}

A repurchase intention is a behavior that arises in response to an object indicating the customer's desire to re-purchase. The re-purchase interest is the tendency stage for consumers to act before the buying decision is actually implemented (Kotler and Keller, 2009). According to Hellier et al (2003), re-purchase intent is defined as an individual's assessment of buying again a designated service in the same company, taking into account the current situation and possible circumstances. Meanwhile, according to Anoraga (2000), repurchase intention is a decisionmaking process made by consumers after having purchased the products offered or required by the consumer. According to Suntara (2008) The interest in buying is a psychic activity that arises due to the feeling of (affective) and the Mind (cognitive) of a desired goods or services.

H5: Customer Perceived Value has a significant impact on Repurchase Intention

\subsection{Customer Satisfaction}

According to Kotler and Keller (2009), Satisfaction is a person's feelings of pleasure or disappointment that result from comparing a product's perceived performance (or outcome) to their expectations. In other words, satisfaction is defined as the feeling of a satisfied or disappointed customer resulting from comparing the perceived performance of the product (or outcome) to the customer's expectation. If performance is under expectation, the consumer is not satisfied. If performance more than expectation, then the consumer will be very happy or satisfied. Kotler and Keller (2009) also say that highly satisfied consumers will usually remain faithful for a long period of time, as well as buy again when the company introduces new products and renews the old product, in addition it will discuss things Both about the company and its products to others, they do not pay much attention to the brand of competitors and not very concerned about the price, they also offer product and service ideas to the company, and the cost of service is cheaper than consumers Transaction becomes a routine thing.

H6: Customer Satisfaction has a significant impact on Repurchase Intention

\subsection{Research Framework}

The research framework of this research as depicted in Figure 1. 


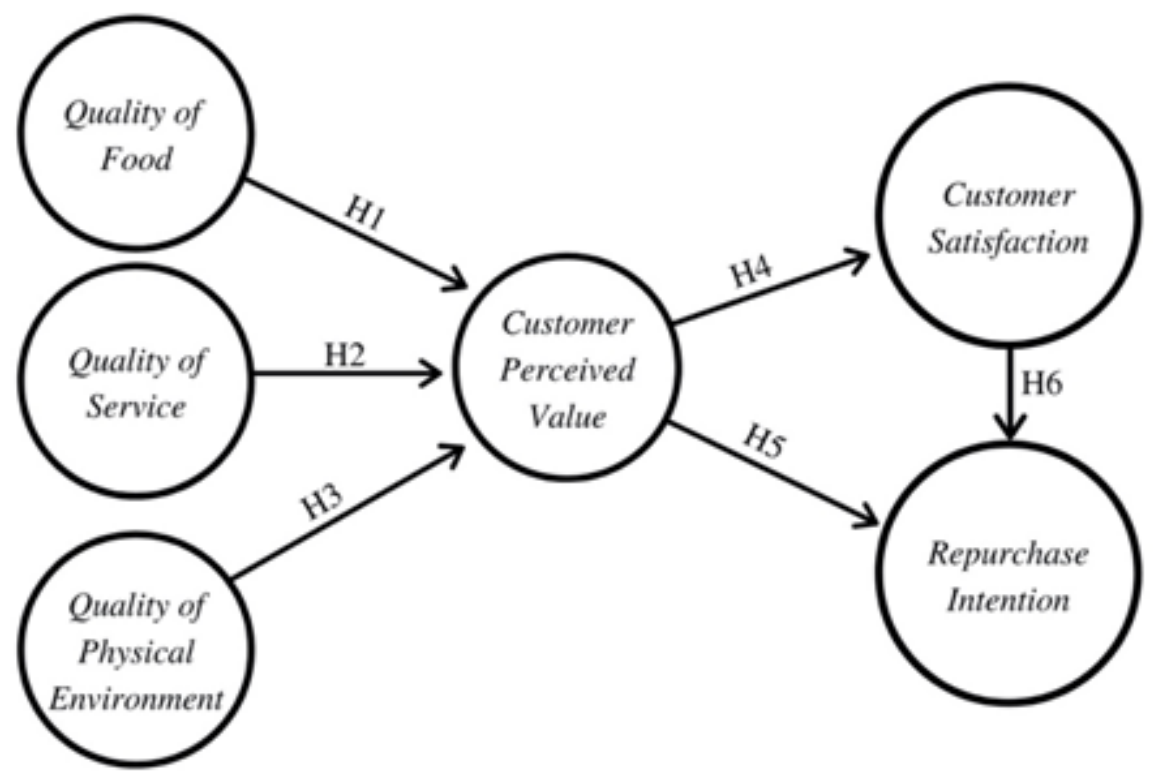

\section{RESEARCH METHODOLOGY}

This research was conducted in Manado, Indonesia, with the O'reillys Restaurant as the object and its consumers as the population. Data was collected by distributing questionnaires to 160 respondents with the characteristics of male and female respondents aged 18-50 years, live in Manado, have visited and bought products from O'reillys Restaurant at least twice in the last 6 months. The method used in this study can process the simultaneous analysis associated with the multi-variable research model which is Structural Equation Model (SEM) using AMOS 20.0 software. Snowball sampling technique was used to choose respondents who could fill out and help distributing the questionnaires. The first part of questionnaire consists of questions used to obtain general information about respondents to ensure the suitability of respondents with sample characteristics. And the second part of questionnaire consists of questions used to obtain research data regarding the impact of Quality of Food, Quality of Service, and Quality of Physical Environment towards Customer Satisfaction and Repurchase Intention with Customer Perceived Value as intervening variable. Likert scale from scale 1-5 was used to formulate the questionnaire, where the answer choices are provided at intervals from $1=$ Strongly Disagree, 2 $=$ Disagree, $3=$ Neutral, $4=$ Agree, and $5=$ Strongly Agree.

\section{RESULT AND DISCUSSION}

\subsection{Profile of Respondent}




\section{International Journal of Social Science and Economic Research}

ISSN: $2455-8834$

Volume: 05, Issue: 01 "January 2020"

There are 220 questionnaires were distributed, but only 160 were returned and could be processed. The result shows that the respondents consist of 89 or $55 \%$ of men and 71 or $45 \%$ of women. The majority of respondents who visit at O'reillys Restaurant were men. The respondents were also classified by age, and those who filled out the questionnaires comprised of 104 or $79,8 \%$ aged $18-30$ years, and 56 or $20.2 \%$ aged $30-50$. All of the respondents live in Manado, has visit and bought products from O'reillys Restaurant at least twice in the last 6 months.

\subsection{Reliability Test}

According to Ferdinand (2002), the composite reliability value should exceed 0.7 to be accepted. Therefore, all of variables used in this research are reliable.

Table 1: Construct Reliability

\begin{tabular}{|c|c|c|c|c|c|}
\hline Variabel & Indikator & $\begin{array}{c}\text { Faktor } \\
\text { Loading } \\
\text { (FL) }\end{array}$ & FL2 & Error & $\begin{array}{l}\text { Construct } \\
\text { Reliability }\end{array}$ \\
\hline \multirow{4}{*}{ Quality Of Food } & $\mathrm{X} 1$ & 0.636 & 0.404 & 0.596 & \multirow{4}{*}{0.731272} \\
\hline & $\mathrm{X} 2$ & 0.518 & 0.268 & 0.732 & \\
\hline & $\mathrm{X} 3$ & 0.485 & 0.235 & 0.765 & \\
\hline & $\mathrm{X} 4$ & 0.42 & 0.176 & 0.824 & \\
\hline \multirow{4}{*}{ Quality Of Service } & $\mathrm{X} 5$ & 0.484 & 0.234 & 0.766 & \multirow{4}{*}{0.746655} \\
\hline & $\mathrm{X} 6$ & 0.43 & 0.185 & 0.815 & \\
\hline & $\mathrm{X} 7$ & 0.607 & 0.368 & 0.632 & \\
\hline & $\mathrm{X} 8$ & 0.669 & 0.448 & 0.552 & \\
\hline \multirow{4}{*}{$\begin{array}{l}\text { Quality Of Physical } \\
\text { Environment }\end{array}$} & $\mathrm{X} 9$ & 0.582 & 0.339 & 0.661 & \multirow{4}{*}{0.793722} \\
\hline & $\mathrm{X} 10$ & 0.665 & 0.442 & 0.558 & \\
\hline & $\mathrm{X} 11$ & 0.687 & 0.472 & 0.528 & \\
\hline & $\mathrm{X} 12$ & 0.719 & 0.517 & 0.483 & \\
\hline \multirow{3}{*}{ Customer Perceived Value } & $\mathrm{X} 13$ & 0.615 & 0.378 & 0.622 & \multirow{3}{*}{0.755312} \\
\hline & $\mathrm{X} 14$ & 0.63 & 0.397 & 0.603 & \\
\hline & $\mathrm{X} 15$ & 0.521 & 0.271 & 0.729 & \\
\hline \multirow{3}{*}{ Customer Satisfaction } & Y1 & 0.525 & 0.276 & 0.724 & \multirow{3}{*}{0.712429} \\
\hline & $\mathrm{Y} 2$ & 0.534 & 0.285 & 0.715 & \\
\hline & Y3 & 0.561 & 0.315 & 0.685 & \\
\hline \multirow{3}{*}{ Repurchase Intention } & Y4 & 0.619 & 0.383 & 0.617 & \multirow{3}{*}{0.778947} \\
\hline & Y5 & 0.598 & 0.358 & 0.642 & \\
\hline & Y6 & 0.599 & 0.359 & 0.641 & \\
\hline
\end{tabular}


International Journal of Social Science and Economic Research

ISSN: 2455-8834

Volume: 05, Issue: 01 "January 2020"

\subsection{Structural Equation Model}

The results of the measurement model on AMOS 20 shown below have RMSEA $=0.078, \mathrm{CMIN}$ / $\mathrm{DF}=1.808$, and there are no indicators with standard loading $<0.5$. Therefore, this model is suitable to be a measurement model for this research.

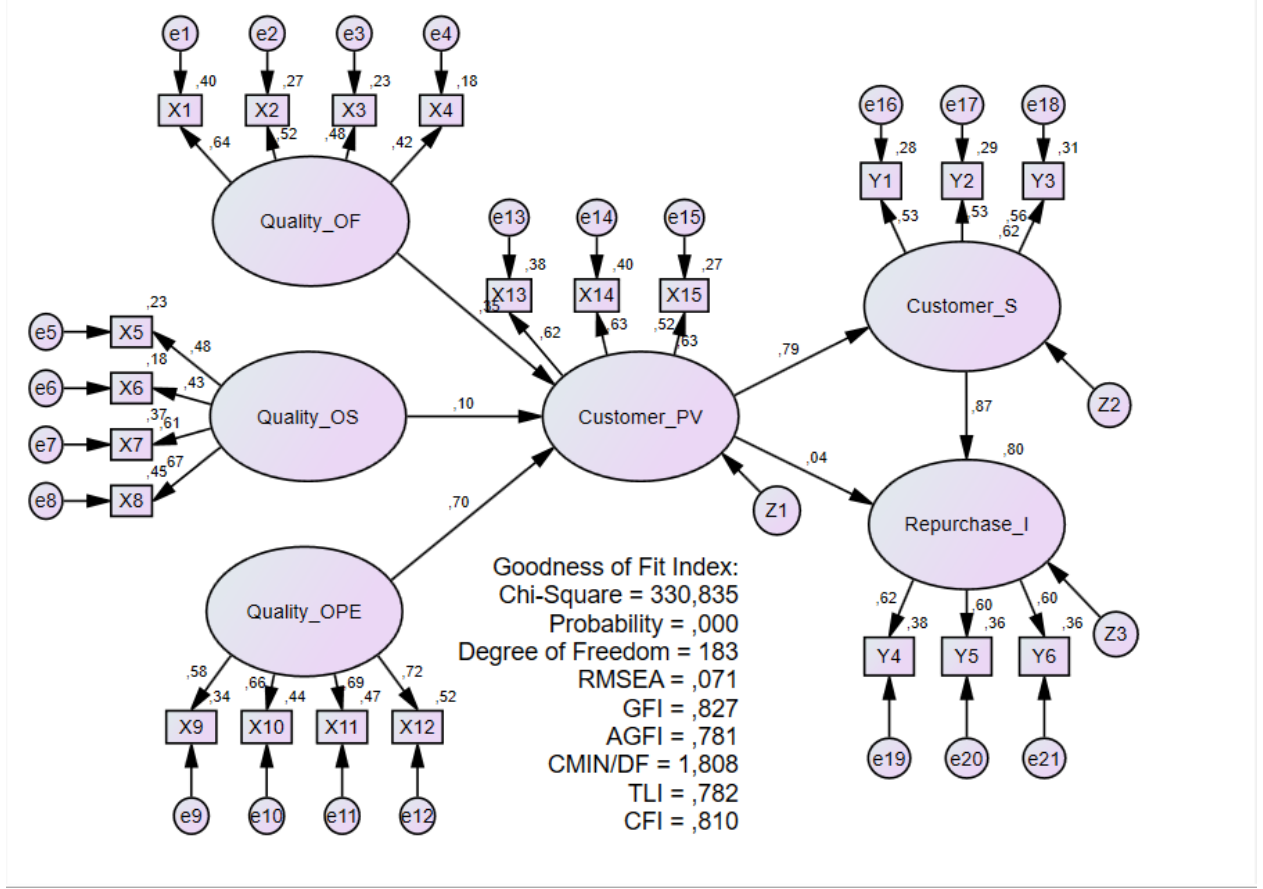

Figure 2: Full Structural Equation Model (SEM)

\subsection{Hypotheses Test}

Hypotheses testing was done by looking at the C.R value for each coefficient. C.R value is significant if $\geq 2$, which means the hypothesis can be accepted. If the value of C.R $<2$ then it is not significant, and the hypothesis is rejected. 
International Journal of Social Science and Economic Research

ISSN: 2455-8834

Volume: 05, Issue: 01 "January 2020"

Table 2: Evaluation of Structural Model Coefficients

\begin{tabular}{|c|c|c|c|c|c|c|c|}
\hline & & & Estimate & S.E. & C.R. & $\mathrm{P}$ & Analysis \\
\hline $\begin{array}{l}\text { Customer } \\
\text { Perceived } \\
\text { Value }\end{array}$ & $<--$ & $\begin{array}{l}\text { Quality of } \\
\text { Food }\end{array}$ & ,344 & ,137 & 2,508 & ,012 & Significant \\
\hline $\begin{array}{l}\text { Customer } \\
\text { Perceived } \\
\text { Value }\end{array}$ & $<--$ & $\begin{array}{l}\text { Quality of } \\
\text { Service }\end{array}$ & ,086 & ,104 & ,823 & ,411 & Not Significant \\
\hline $\begin{array}{l}\text { Customer } \\
\text { Perceived } \\
\text { Value }\end{array}$ & $<---$ & $\begin{array}{l}\text { Quality of } \\
\text { Physical } \\
\text { Environment }\end{array}$ &, 554 & ,132 & 4,207 & $* * *$ & Significant \\
\hline $\begin{array}{l}\text { Customer } \\
\text { Satisfaction }\end{array}$ & $<--$ & $\begin{array}{l}\text { Customer } \\
\text { Perceived } \\
\text { Value }\end{array}$ & ,801 & ,184 & 4,352 & $* * *$ & Significant \\
\hline $\begin{array}{l}\text { Repurchase } \\
\text { Intention }\end{array}$ & $<--$ & $\begin{array}{l}\text { Customer } \\
\text { Perceived } \\
\text { Value }\end{array}$ & ,043 & ,365 &, 118 & ,906 & Not Significant \\
\hline $\begin{array}{l}\text { Repurchase } \\
\text { Intention }\end{array}$ & $<---$ & $\begin{array}{l}\text { Customer } \\
\text { Satisfaction }\end{array}$ & ,995 & ,438 & 2,271 & ,023 & Significant \\
\hline
\end{tabular}

The result shows that there are 4 significant variables as shown on table, which means $\mathrm{H} 1, \mathrm{H} 3$, H4, and H6 were accepted. The Quality of Physical Environment variable has the highest C.R value, which is 4,207, which means this is the most important variable in this research. It is explained that in order to increase Customer Perceived Value of O'Reillys restaurant customers, then the main thing to improve is the attractive room design, pleasant background music, the staff at O'Reillys restaurant have to look neat and polite and the restaurant has clean furniture. Quality of food variable has the second highest C.R value which is 2,508. It is explained that in order to increase Customer Perceived Value of O'Reillys restaurant customers, then the focus is to serve good food, serving nutritious food, serving food that matches the tastes of consumers and serves fresh food. Quality of Service has the lowest C.R value which is 0,823 and doesn't have significant impact on Customer Perceived Value. But if the restaurant wants to improve to be the best restaurant in town, they should improve everything include the Quality of Service.

\section{CONCLUSION}

The result of this study shows that Quality of Food and Quality of Physical Environment have a significant impact on Customer Perceived Value, Customer Perceived Value have a significant impact on Customer Satisfaction, and Customer Satisfaction have a significant impact on Repurchase Intention. Meanwhile, Quality of Service have no significant impact on Customer 
Perceived Value and Customer Perceived Value have no significant impact on Repurchase Intention.

\subsection{Managerial Implication}

The managerial implication will be based on indicators used in the distributed questionnaires. The recommendations are explained starting from indicators that have the highest impact to the lowest impact for each variable.

\begin{tabular}{|l|l|}
\hline \multicolumn{1}{|c|}{ Current Research } & \multicolumn{1}{|c|}{ Managerial Implication } \\
\hline $\begin{array}{l}\text { Quality of Physical Environment is a } \\
\text { variable that has the biggest impact to }\end{array} \mid \begin{array}{l}\text { O'Reillys restaurant needs to do } \\
\text { regular maintenance so that every part } \\
\text { of the room is maintained, otherwise it } \\
\text { is necessary to also make a functional } \\
\text { room for example for a room that is } \\
\text { smoke-free, then a room that is family } \\
\text { friendly or for fine dining. } \\
\text { O'Reillys restaurant needs to provide } \\
\text { background music that is suitable with } \\
\text { the ambience that customer want to } \\
\text { enjoy, especially if O'Reillys } \\
\text { restaurant is applying thematic } \\
\text { concept, it will make it easier to find } \\
\text { the song to be played, while for live } \\
\text { Music needs to invite a good singers } \\
\text { who have a high reputation with a } \\
\text { cheap price rate and who can bring a } \\
\text { lot of crowd, this will give good } \\
\text { impact to the restaurant. } \\
\text { O'Reillys restaurant needs to pay } \\
\text { attention to how each staff looks, it } \\
\text { will be better for the staff to be given a } \\
\text { varied uniform every day or every } \\
\text { week, made by thematic according to } \\
\text { the concept carried by the O'Reillys } \\
\text { restaurant, For example, when } \\
\text { Hallowen, the staffs dressed that } \\
\text { match the theme Hallowen or during }\end{array}$ \\
\hline
\end{tabular}




\begin{tabular}{|c|c|}
\hline & $\begin{array}{l}\text { National Independence Day, the staffs } \\
\text { were dressed that matched the theme. } \\
\text { This affects every customer feeling } \\
\text { who comes in. } \\
\text { - O'Reillys Restaurant should keep the } \\
\text { cleanliness of each furniture and } \\
\text { adding an exclusive impression by } \\
\text { selecting the furniture and design of a } \\
\text { classy room without compromising } \\
\text { the comfort of the customer so that the } \\
\text { customer feels the high-end place. }\end{array}$ \\
\hline $\begin{array}{l}\text { Quality of Food is a variable that has } \\
\text { impact to increase Customer Perceived } \\
\text { Value }\end{array}$ & $\begin{array}{l}\text { - O'reilllys ' restaurant needs to provide } \\
\text { training to get a certification for the } \\
\text { cheff and hopefully can adding some } \\
\text { insight and knowledge to create a } \\
\text { great meal, for example O'Reillys } \\
\text { restaurant has a typical Italian food } \\
\text { taste, the cheff needs to learn in Italy } \\
\text { and try Italian food. } \\
\text { O'Reillys restaurant needs to make a } \\
\text { healthy menu such as salad or sliced } \\
\text { fresh fruit, and fruit drinks mixed with } \\
\text { alcohol, such as cocktail but made } \\
\text { from fresh fruit. } \\
\text { O'Reillys Restaurant should conduct } \\
\text { research and development on the tastes } \\
\text { of consumers by means of trial and } \\
\text { error, hoping to find food that matches } \\
\text { the tastes of the majority of customers } \\
\text { in O'Reillys restaurant. It is also } \\
\text { necessary to be supported by } \\
\text { recruiting Professional and certified } \\
\text { mixologist or bartender to be able to } \\
\text { serve the customer well. } \\
\text { Another thing to note also is the use of } \\
\text { preservatives, which need to be } \\
\text { restricted and should even be avoided }\end{array}$ \\
\hline
\end{tabular}


International Journal of Social Science and Economic Research

ISSN: 2455-8834

Volume: 05, Issue: 01 "January 2020"

\begin{tabular}{|c|c|}
\hline & $\begin{array}{l}\text { to produce more fresh food and did not } \\
\text { disturb customer health. }\end{array}$ \\
\hline $\begin{array}{l}\text { Quality of Service in this does not has } \\
\text { impact on Customer Perceived Value }\end{array}$ & $\begin{array}{l}\text { - O'Reillys restaurant needs to innovate } \\
\text { using technology, which is to prepare } \\
\text { a tablet for each staff when receiving } \\
\text { orders, and the system of the tablet } \\
\text { integrated with the LCD in the } \\
\text { kitchen, so the cheff can directly } \\
\text { prepare the order quickly. } \\
\text { - O'Reillys Restaurant should raise the } \\
\text { awareness and sensitivity of the staffs } \\
\text { by always doing a briefing before } \\
\text { starting work, so that staff can prepare } \\
\text { and always willing to serve customer. } \\
\text { In addition, it is necessary to add the } \\
\text { bell button from each table, so that } \\
\text { whenever a customer needs a staff, the } \\
\text { customer can press the bell button that } \\
\text { has been provided. } \\
\text { Adding some things to the Company's } \\
\text { Operational Standards that prioritizes } \\
\text { hospitality that makes the customer } \\
\text { feel appreciated, such as greetings, } \\
\text { slogans, and closing greetings after } \\
\text { completing the transaction. } \\
\text { O'Reillys Restaurant should conduct } \\
\text { training to the staffs to improve their } \\
\text { knowledge about the products in the } \\
\text { restaurant, in addition to training the } \\
\text { language style and way of delivery } \\
\text { from the staff in order to inform the } \\
\text { menus that correspond to the customer } \\
\text { desire. }\end{array}$ \\
\hline
\end{tabular}

Based on the result, the main recommendation that needs to be done for this research object is to make new innovations to improve Customer Satisfaction and Repurchase Intention, where the most influential is the variable Quality of Physical Environment. Thus, the O'Reillys restaurant 


\section{International Journal of Social Science and Economic Research}

ISSN: $2455-8834$

Volume: 05, Issue: 01 "January 2020"

should conduct more training to the staff to increase their knowledge of the products in the restaurant, and also to practice the language styles and delivery from the staff in order to inform the menus that correspond to the customer's wishes. As well as adding some things to the Company's Operational Standards that prioritizes hospitality that makes the customer feel appreciated, such as greeting, slogan, and greeting after finishing transaction. In addition, O'Reillys restaurant should raise the awareness and sensitivity of the staffs by always doing a briefing before starting work, so that staff can be prepare and always willing to serve customer. And conducting motivational seminars or go out together with the whole staff where the activities of all staff can evaluate each other and improve their performance.

\subsection{Recommendations}

Further researches can be done by considering these limitations as follows:

1. This research object is only limited to O'reillys Restaurant consumers in Manado. Further research can be carried out using broader research objects, to get other results regarding factors that impact Customer Satisfaction and Repurchase Intention.

2. The result of this study can't be generalized for cases outside of this research object, which is O’reillys Restaurant.

3. Further research to complement the variables exist in this study needs to be done to further refine the understanding of the factors that has impact on Customer Satisfaction and Repurchase Intention.

\section{REFERENCES}

[1] Anoraga, Pandji. Business Management. Jakarta. 2000. Publisher: PT Rineka Cipta.

[2] Brady, M. K., \& Cronin, J. J. Some new thoughts on conceptualizing perceived service quality: A hierarchical approach. 2001. The Journal of Marketing Vol.65, p.34-49.

[3] Chaplin, J P. Kamus Lengkap Psikologi. 2005. Jakarta: Rajawali Press

[4] Cravens and Piercy. Strategic Marketing 8th Edition. 2006. McGraw-Hill Irwin

[5] Cronin, J., Joseph, Jr., Steven A., \& Taylor. Measuring service quality: A reexamination and extention. 1992. Journal of Marketing, 56(3), p.55-68.

[6] Dutka, Alan. AMA Handbook for Customer Satisfaction. NTC Business Book, 2010, Lincolnwood, Illinois.

[7] Evirasanti et al. Pengaruh Kualitas Makanan, Kualitas Layanandan Lingkungan Fisik Terhadap Kepuasan Dan Behavioral Intentions (Studi Di Métis Restaurant). 2016. Fakultas Ekonomi dan Bisnis Universitas Udayana (Unud) - Bali, Indonesia 
International Journal of Social Science and Economic Research

ISSN: $2455-8834$

Volume: 05, Issue: 01 "January 2020"

[8] Fadilah, Dewi dan Sari Lestari Zainal Ridho. Perilaku Konsumen. 2013. Palembang: Citra Books Indonesia

[9] Fornel, C. A national customer satisfaction barometer: The swedish experience. 1992. Journal of Marketing, 56(1),6-21

[10] Gaspersz, V. Total Quality Managament. 2008. Jakarta: Penerbit Gramedia Pustaka Utama

[11] Griffin, Jill. Customer Loyalty: Menumbuhkan dan Mempertahankan Kesetiaan Pelanggan. Alih bahasa: Dwi Kartini Yahya dan kawan kawan. 2010. Erlangga, Jakarta.

[12] Gunarso, Singgih, D. dan Yulia Singgih D. Gunarso. Psikologis Praktis Anak, Remaja dan Keluarga. 2005. Penerbit BPK Gunung Mulia.Sab'atun, Jakarta.

[13] Handi, Irawan D. 10 Prinsip Kepuasan Pelanggan. 2009. Elex Media Komputindo, Jakarta.

[14] Hamdani dan Rambut Lupiyoadi. Manajemen Pemasaran Jasa. 2009. Salemba Empat. Jakarta,

[15] Harjanto, J.O. Inovasi Produk dan Ekspektasi Inovasi terhadap Keputusan Pembelian Konsumen. 2009.

[16] Hellier, P.K., Geursen, G.M., Carr, R.A. and Rickard, J.A. Customer Repurchase Intention. A General Structural Equation Model. 2003. European Journal of Marketing, Vol. 37 No. 11/12, pp. 1762-1800.

[17] Heru, S. Hubungan antara kualitas \& kepuasan pelanggan dalam pembentukan intensi pembelian pelanggan: Studi pada empat industri jasa di Semarang. 1999. Jurnal Bisnis Strategi, 2(4).

[18] Ismail, I., Haron, H., Ibrahim, D.N., and Isa, S.M. Service Qualtiy Cliente Satisfaction and Loyality Toward Audit Firm: Perseptionis of Malaysia Public Listen Companys. 2006. Manajerial Auditing Journal, 21(7), pp:738- 756.

[19] Kotler, P. \& Armstrong, G. Prinsip-Prinsip Pemasaran. 2008. Edisi 12. Jilid 1. Jakarta: Erlangga

[20] Kotler, Philip; Armstrong, Gary. Principles of Marketing. 2012. Fourteenth Edition. Pearson, p. 248.

[21] Kotler P. \& Keller Kevin Lane, Manajemen Pemasaran. 2009. Edisi Ketiga Belas, Jilid 1. Jakarta: Erlangga

[22] Kotler, Philip. Manajemen Pemasaran 1. 2002. Millineum ed. Jakarta: PT Prenhallindo.

[23] Kumar, V., Reinartz, W. Creating enduring customer value. 2016. J Market. 80 (6), 3668.

[24] Lin, Chia C. 2003, "The Role of Customer Perceived Value in Generating Customer Satisfaction: An E- Bussiness Perspective," Journal of Research in Marketing \& Entrepreneurship, Vol. 5, No. 1, pp. 25- 39. 


\section{International Journal of Social Science and Economic Research}

ISSN: $2455-8834$

Volume: 05, Issue: 01 "January 2020"

[25] Lovelock, Christopher \& Jochen Wirtz. 2004. Services Marketing Fifth Edition People, Technology, Strategy. New York: Pearson.

[26] Lovelock, C., Wirtz, J., Hean Tatkeh \& Xiongwen Lu., 2005 Services Marketing in Asia. Fith Edition Singapore: Prentice Hall.

[27] Marsum, A. W. Restoran dan Segala Permasalahannya. (Ed.4). 2005. Yogyakarta: Andi.

[28] Parasuraman, A., Valarie A. Zeithaml and Leonard L. Berry. SERVQUAL: A MultipleItem Scale for Measuring Consumer Perceptions of Service Quality. 1988. Journal of Retailing. Vol. 64 No. 1, pp.12-40.

[29] Payne A. The Essence of Service Marketing. 2001. New York: Prentice Hal, Inc.

[30] Potter, N. N and Hotckiss, J. H. Principles of Food Packaging. In: Food Science, Food Science Text Series. 1995. Springer, Boston,

[31] Rachmawati, Rina. Peranan Bauran Pemasaran (Marketing Mix) terhadap Peningkatan Penjualan (Sebuah Kajian terhadap Bisnis Restoran). Jurusan Teknologi Jasa dan Produksi. 2011. Universitas Negeri Semarang

[32] Rangkuti, Freddy. Measuring Customer Satisfaction. 2009. PT. Gramedia Pustaka Utama, Jakarta.

[33] Ratnawati. Mengukur Kepuasan Masyarakat terhadap Pelayanan Pendidikan. Jurnal Pendidikan. No. 043. Juli 2002.

[34] Rintamäki, T., Kirves, K. From perceptions to propositions: profiling customer value across retail contexts. J. Retail. Consum. 2017. Serv. 37, 159-167.

[35] Rustan, Surianto. Layout Dasar Dan Penerapannya. 2008. Jakarta: Gramedia.

[36] Ryu, Kisang, Heesup Han and Tae-Hee Kim. The relationships among overall quickcasual restaurant image, perceived value, customer satisfaction, and behavioral intentions. 2008. International Journal of Hospitality Management. Vol. 27, Iss.3, pp.459-469.

[37] Ryu, Kisang and Heesup Han. The Influence of the Quality of Food, Service, and Physical Environment on Customer Satisfaction and Behavioral intentions in QuickCasual Restaurants: Moderating Role of Perceived Price. 2010. Journal of Hospitality \& Tourism Research. Vol. 34 No.3, pp. 310-329.

[38] Sab'atun, I. Minat Membeli Kosmetik Produk Luar Negeri Ditinjau Dari Penerimaan Diridan Dukungan Sosial Dikalangan Pragawati. Skripsi. Surakarta: Fakultas Psikologi UMS. 2001.

[39] Schiffman LG, LL Kanuk. Consumer Behavior 9th editions. Upper Saddle River, New Jersey, Prentice-Hall, Inc. 1997.

[40] Sukresno. Management Food and Beverage Service Hotel. 2006.

[41] Sulartiningrum. Pengantar Akomodasi dan Restoran. Jakarta: Gramedia Pustaka Utama. 2003. 
International Journal of Social Science and Economic Research

ISSN: 2455-8834

Volume: 05, Issue: 01 "January 2020"

[42] Suntara. Hubungan Antara Sikap Menonton Iklan Rinso di Televisi Terhadap Minat Beli Pada Ibu Ibu Kelurahan Sangkrah. Skripsi. Fakultas Psikologi UMS. Surakarta. 2008.

[43] Supranto, J. Pengukuran Tingkat Kepuasan Pelanggan untuk Menaikkan Pangsa Pasar, Cetakan Ketiga. Jakarta: PT.Rineka Cipta. 2006.

[44] Sangadji, E. M., \& Sopiah, Consumer Behavior: Perilaku Konsumen dan Strategi Pemasaran Jilid 2. Jakarta: Erlangga. 2013.

[45] Schiffman, Leon G. dan Leslie Lazar Kanuk. Consumer Behavior Tenth Edition. Pearson Education. 2010.

[46] The Liang Gie. Cara Belajar yang Efisien. Jilid II ed. 4. Bandung: ITB. 2005.

[47] Tjiptono, F. Strategi pemasaran. Malang: Bayu Media Publishing. 2012.

[48] Wakefield, K. L., \& Blodgett, J. G., The Effect of the Servicescape on Customers Behaviors in Intention Service Leisure Setting. Journal of Service Marketing, vol 10, p45-61. 1999.

[49] West, Wood \& Harger. Food service in Intuitions. 1965. New York: John Wiley \& Sons, Inc.

[50] West, W., \& Harger. Advertising \& Promotion: an IMC Perspective. 2007.

[51] Widjaja, B.T. Lifestyle Marketing. 2009. Jakarta: PT. Gramedia Pustaka Utama.

[52] Yaqian Zhou. The Impact of Customer-Based Brand Equity on Revisit Intentions: An Empirical Study of Business and Leisure Travelers at Five Shanghai Budget Hotels. 2011.

[53] Zeithaml VA, Bitner MJ \& Gremler, Dwaine D. Services Marketing (Integrating Customer Focus Across the Firm) 4th edition McGraw Hill Irwin, New York. 1996.

[54] Zeithalm, V. A., Bitner, M. J. \& Gremler, D. D., Services Marketing. Fourth Edition, Singapore: McGraw-Hill. 2006.

[55] Zeithaml, V. A. Consumer perceptions of price, quality, and value: A means-end model and synthesis of evidence. 1988. Journal of Marketing, vol 52, p2-22. 